\title{
PENGARUH SUHU PENGERINGAN SPRAY DRYER TERHADAP SIFAT FISIK DAN AKTIVITAS ANTIOKSIDAN TABLET EKSTRAK BUAH MAHKOTA DEWA (Phaleria macrocarpa Boerl.)
}

\author{
Irfanianta Arif Setyawan ${ }^{1}$, Yandi Syukri ${ }^{2}$, Hady Anshory ${ }^{2}{ }^{1}$ Program Studi Farmasi Institut Teknologi \\ Sumatera ${ }^{2}$ Program Studi Farmasi Universitas Islam Indonesia
}

\begin{abstract}
Phaleria (Phaleria macrocarpa Boerl.) contains flavonoids with antioxidants to prevent free radical that can cause cancer. This study aimed to determine the effect of drying temperature in spray dryer on the physical properties and antioxidant activity of the tablet from mahkota dewa fruit extract. Extraction process was performed by percolation technique with ethanol $70 \%$. Extracts were made into powder using a spray dryer with a variation of drying temperature. The tablets were produced by direct compression method then the physical properties of powder, tablets physical properties and antioxidant activity were tested. Based on the results, the tablet with drying temperature of $70^{\circ} \mathrm{C}$ produced $6.9 \pm 0.52 \mathrm{~kg}$ hardness, $7.38 \pm 0.21$ minutes disintegration time and $6.80 \pm 2.85 \%$ free radical inhibition activity. Tablet with drying temperature of $90^{\circ} \mathrm{C}$ produced $7.55 \pm 0.35 \mathrm{~kg}$ hardness, $7.37 \pm 0.11$ minutes disintegration time, and $3.68 \pm 0.73 \%$ free radical inhibition activity. Tablet with drying temperature of $110^{\circ} \mathrm{C}$ produced $8.33 \pm 0.21 \mathrm{~kg}$ hardness, $8.49 \pm 0.08$ minutes disintegration time, and $1.84 \pm 0.87 \%$ free radical inhibition activity. The results of this research showed that the increasingly of spray dryer temperature effect on the higher of tablet hardness and disintegration time, also decrease the anti oxcidant activity $(p<0.05)$.
\end{abstract}

Keyword: Phaleria, tablet, spray dryer, antioxidants

\section{Pendahuluan}

Kekayaan alam yang dimiliki oleh Indonesia sangat melimpah dan beranekaragam akan tetapi pemanfaatannya masih belum optimal. Hal ini menginspirasi masyarakat Indonesia untuk dapat memanfaatkan kekayaan alam tersebut sebagai alternatif dalam segala hal termasuk pengobatan. Pengobatan tradisional dengan menggunakan bahan alam baik yang berasal dari tanaman, hewan maupun mineral telah dikenal sejak dahulu ${ }^{(1)}$. Saat ini pengobatan dengan obat tradisional dijadikan salah satu pilihan alternatif dalam pengobatan karena memiliki beberapa keuntungan yaitu harga yang relatif lebih murah dan bahan baku yang mudah diperoleh ${ }^{(2)}$.

Mahkota dewa (Phaleria macrocarpa L.) adalah tanaman perdu dari suku Thymelaceae yang tumbuh subur pada dataran rendah hingga ketinggian 1200 meter di atas permukaan laut ${ }^{(3)}$. Tanaman Mahkota Dewa (Phaleria macrocarpa) telah digunakan secara tradisional untuk pengobatan kanker di Indonesia ${ }^{(4)}$. Hasil penelitian menunjukkan bahwa daging buah dan cangkang biji mahkota dewa mengandung beberapa senyawa antara lain alkaloid, flavonoid, senyawa polifenol, dan tanin ${ }^{(5)}$. Senyawa fenolik atau flavonoid yang juga terkandung dalam buah mahkota dewa menunjukkan aktivitas antioksidan yang poten ${ }^{(6)}$.

Aktivitas antioksidan yang dimiliki buah mahkota dewa dikarenakan kandungan flavonoid yang tinggi pada buah mahkota dewa dibandingkan dengan bagian tanaman yang lainnya ${ }^{(7)}$. Sebelumnya telah dilakukan penelitian tentang potensi efek antikanker ekstrak buah mahkota dewa diketahui bahwa ekstrak etanol buah mahkota dewa memiliki potensi sebagai antikanker. Dosis efektif ekstrak buah mahkota dewa yang memberikan efek antikarsinogenik adalah dosis ekstrak $25 \mathrm{mg}$ yang setara dengan $200 \mathrm{mg}$ serbuk buah mahkota dewa ${ }^{(8)}$.

Akhir-akhir ini tanaman mahkota dewa banyak digunakan sebagai obat tradisional, baik secara tunggal maupun dicampur dengan obat-obatan tradisional lainnya ${ }^{(9)}$. Pada umumnya pemanfaatan produk bahan alam dari tumbuhan ini masih menggunakan cara tradisional sehingga tidak terjamin keseragaman dosis dari sediaan yang digunakan ${ }^{(10)}$. Sehingga untuk meningkatkan kepraktisan dan kestabilannya serta keseragaman dosis perlu dikembangkan bentuk sediaan yang lebih baik ${ }^{(11)}$. Salah satu alternatif yang dapat dilakukan adalah dengan membuat ekstrak buah mahkota dewa ke dalam bentuk sediaan tablet sehingga dapat menjamin ketepatan dosis dan memiliki beberapa keuntungan diantaranya yaitu mudah digunakan, nyaman dan merupakan sediaan kering yang stabil.

Pengeringan merupakan salah satu bagian penting dalam proses pembuatan tablet ekstrak buah mahkota dewa. Pengeringan didefinisikan sebagai proses penghilangan cairan dari bahan dengan 
menggunakan panas ${ }^{(12)}$. Pengeringan bertujuan untuk melindungi obat dari pengaruh degradasi, karena kecepatan degradasi akan bertambah cepat bila material masih dalam bentuk larutan atau lembab (basah). Selain itu, pengeringan juga bertujuan untuk memperbaiki sifat alir granul, melindungi obat dari pengaruh organisme, memudahkan proses pengecilan partikel dan meningkatkan stabilitas produk yang dikemas ${ }^{(13)}$. Proses pengeringan yang melibatkan pemanasan dengan suhu yang relatif tinggi dan waktu pemanasan yang lama dapat mempengaruhi aktivitas antioksidan yang dimiliki flavonoid yang terkandung ekstrak buah mahkota dewa. Pada penelitian ini proses pengeringan ekstrak buah mahkota dewa dilakukan dengan menggunakan spray dryer dengan mengoptimasi kondisi proses pengeringan. Penggunaan spray dryer dikarenakan spray dyer dapat digunakan untuk mengeringkan bahan-bahan yang peka terhadap panas tanpa merusak bahan-bahan tersebut, meskipun menggunakan udara bertemperatur tinggi ${ }^{(14)}$. Selain itu pemaparan panas yang terjadi dalam waktu singkat mengakibatkan perusakan produk karena panas jarang terjadi ${ }^{(13)}$. Proses pengeringan ekstrak buah mahkota dewa dengan menggunakan spray dryer dilakukan pada suhu $70^{\circ} \mathrm{C}, 90^{\circ} \mathrm{C}$ dan $110^{\circ} \mathrm{C}$. Pemilihan suhu pengeringan spray dryer berdasarkan titik didih yang dimiliki etanol $70 \%$ sebagai pelarut ekstrak buah mahkota dewa yang digunakan yaitu pada suhu $78^{\circ} \mathrm{C}^{(15)}$. Adanya variasi suhu spray dryer yang digunakan dalam proses pengeringan ekstrak buah mahkota dewa pada penelitian ini dapat berpengaruh terhadap bentuk, sifat alir, kerapatan dan kualitas serbuk ekstrak buah mahkota dewa yang dihasilkan, sehingga dapat berpengaruh juga terhadap sifat fisik tablet jika serbuk ekstrak buah mahkota dewa kemudian diformulasikan menjadi sediaan tablet. Selain itu adanya pemanasan dengan suhu yang relatif tinggi dan waktu pemanasan yang lama selama proses pengeringan dapat merusak senyawa antioksidan yang terkadung di dalam ekstrak buah mahkota dewa. Hal ini dapat berpengaruh terhadap aktivitas antioksidan ekstrak buah mahkota dewa setelah diformulasikan menjadi sedian tablet.

Tablet merupakan salah satu bentuk sediaan yang praktis untuk dikonsumsi. Tablet yang baik tergantung pada kualitas komposisi dan proses pembuatannya. Dalam pembuatan tablet, karakteristik dari semua bahan (zat aktif dan bahan pembantu), serta proses produksi akan mempengaruhi sifat fisik tablet yang dihasilkan dan juga ketersediaan hayati zat aktif tersebut di dalam tablet ${ }^{(16)}$. Serbuk merupakan partikel-partikel padat penyusun komposisi suatu sediaan tablet. Sifat-sifat dari serbuk sangat berpengaruh terhadap keberhasilan proses produksi, stabilitas dan keefektifan sistem penghantaran obat suatu sediaan tablet. Untuk mendapatkan serbuk ekstrak buah mahkota dewa yang memiliki kualitas tinggi maka perlu dilakukan penelitian lebih lanjut pada proses produksinya. Penelitian ini dilakukan untuk melihat adanya pengaruh variasi suhu pengeringan ekstrak buah mahkota dewa selama proses produksi serbuk ekstrak buah mahkota dewa dengan menggunakan spray dryer terhadap sifat fisik dan aktivitas antioksidan tablet ekstrak buah mahkota dewa yang dihasilkan.

\section{Alat, Bahan, dan Metode}

\subsection{Alat}

LabPlant ${ }^{\circledR}$ SD Basic Spray Dryer, perkolator, blender, bejana penjenuhan, pipa kapiler, sinar UV 254 dan 365nm, pengayakan, oven, mesin pencetak tablet single punch (Korsch/EK-0), hardness tester (Vanguard), friabilator (Erweka/TA-100), disentegrator tester (Erweka ZT 502), alat uji sudut diam, pengukur waktu alir, tapped density tester, Moisturebalance, micrometer, neraca analitik tipe Dragon 204 (Mettler Toledo) dan seperangkat alat gelas.

\subsection{Bahan}

Bahan baku yang digunakan adalah buah mahkota dewa (Phaleria macrocarpa Boerl.) dari Merapi Farma, etanol 70\% dari Brataco, akuades, avicel PH 102 dari Brataco, primojel dari Brataco, aerosil dari Brataco, magnesium stearat dari Brataco. Semua bahan baku yang digunakan memiliki kualitas farmasetis. Fase gerak KLT BAW 4:1:5 (butanol: asam asetat: water), silika gel $60 \mathrm{~F}_{254}$, amoniak, standar rutin, maltodekstrin, DPPH 1,1 Diphenyl-2-picrylhidrazyl -(Sigma- aldrich), vitamin E ( $a$ tokoferol- E- Merck).

\subsection{Metode}

Penelitian dilakukan dalam beberapa tahapan yang meliputi: identifikasi simplisia buah mahkota dewa, pembuatan dan evaluasi ekstrak, pengeringan ekstrak buah mahkota dewa dengan menggunakan spray dryer, pembuatan tablet, evaluasi tablet meliputi sifat fisik dan aktivitas antioksidan.

Identifikasi buah mahkota dewa dilakukan dengan pemeriksaan secara organoleptik untuk mendeskripsikan bentuk, warna, bau dan rasa dari simplisia buah mahkota dewa (Phaleria macrocarpa Boerl.) dan kemudian dicocokkan dengan identitas simplisia buah mahkota dewa yang terdapat dalam literatur yaitu Farmakope Herbal Indonesia. 
Pembuatan ekstrak dilakukan dengan teknik perkolasi menggunakan etanol $70 \%$. Ekstrak yang diperoleh selanjutnya dievaluasi meliputi pemeriksaan organoleptik, perhitungan rendemen, pengujian kadar air ekstrak dan identifikasi kandungan senyawa.

Ekstrak cair yang diperoleh dari hasil ekstraksi buah mahkota dewa ditambah dengan maltodekstrin $10 \%$ dan kemudian dikeringkan dengan menggunakan spray dryer untuk mendapatkan serbuk ekstrak buah mahkota dewa. Maltodekstrin berfungsi untuk mengikat ekstrak dan mengurangi ekstrak yang lengket pada spray dryer. Pada penelitian ini dilakukan variasi suhu pengeringan spray dryer yaitu pada suhu $70^{\circ} \mathrm{C}, 90^{\circ} \mathrm{C}$ dan $110^{\circ} \mathrm{C}$.

Serbuk ekstrak hasil spray dryer pada masing-masing suhu pengeringan selanjutnya dicampurkan dengan eksipien tablet dan dilaukan evaluasi sifat fisik serbuk kemudian dicetak menjadi sediaan tablet dengan metode kempa langsung. Dilakukan evaluasi sifat fisik tablet dan aktivitas antioksidan tablet yang dihasilkan. Aktivitas antioksidan dihitung dengan menggunakan rumus \% aktivitas penghambatan radikal bebas dari DPPH dalam persen, yaitu:

Analisis hasil evaluasi sifat fisik tablet dan aktivitas antioksidan tablet dengan metode DPPH, selanjutnya dilakukan analisis hasil dengan uji statistik one way ANOVA dengan tingkat kepercayaan $95 \%$. Dibandingakan sifat fisik dan daya antioksidan antara tablet dengan suhu pengeringan $70^{\circ} \mathrm{C}$, $90^{\circ} \mathrm{C}$ dan $110^{\circ} \mathrm{C}$. Data yang didapat kemudian dianalisis dengan uji statistik one way ANOVA dan dibandingkan nilai signifikansinya. Dengan rancangan ini dapat diuji apakah antar formula dengan variasi suhu pengeringan terdapat perbedaan yang bermakna.

\section{Hasil dan Pembahasan}

Hasil pemeriksaan yang dilakukan secara organoleptik terhadap bentuk, warna, bau dan rasa dari simplisia buah mahkota dewa (Phaleria macrocarpa Boerl.) adalah bentuk berupa rajangan, berwarna putih kekuningan sampai dengan ungu tua di daerah tepi, bau yang khas dan rasa yang pahit.

Dari hasil ekstraksi $1 \mathrm{~kg}$ serbuk simplisia kering mahkota dewa untuk menghasilkan ekstrak kental sebanyak 207,9 g, sehingga diperoleh rendemen sebesar 20,79\%. Hasil uji KLT bercak berwarna kuning pada kromatogram yang terlihat dengan lampu visible menunjukkan adanya flavonoid. Karakter ekstrak berbentuk cairan kental, warna coklat, bau aromatis dan memliki rasa pahit. Kadar

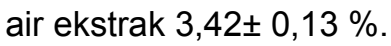

Tabel 1. Hasil uji sifat fisik serbuk tablet ekstrak buah mahkota dewa

\begin{tabular}{|c|c|c|c|}
\hline \multirow[t]{2}{*}{ Evaluasi } & \multicolumn{3}{|c|}{ Formula (X \pm SD) } \\
\hline & $T$ & $\pi$ & TII \\
\hline Sudut diam $\left({ }^{\circ}\right)$ & $27,48 \pm 0,42$ & $26,32 \pm 0,63$ & $27,01 \pm 1,62$ \\
\hline Index Pengetapan (\%) & $23,00 \pm 0,00$ & $23,00 \pm 0,00$ & $24,00 \pm 0,00$ \\
\hline Carrs Index (\%) & $22,98 \pm 0,68$ & $23,46 \pm 0,23$ & $24,42 \pm 0,24$ \\
\hline
\end{tabular}

Dari ketiga formula diatas memiliki sudut diam yang baik karena nilai sudut diam $\leq 30^{\circ}$. Indeks pengetapan dari ketiga formula berkisar antara $23 \%$ sampai $24 \%$. Hal ini menunjukkan ketiga formula memiliki indeks pengetapan yang kurang baik karena memiliki indeks pengetapan yang lebih dari $15 \%$, sehingga perlu dilakukan penambahan glidan untuk memperbaiki sifat alirnya. Pada evaluasi Carr Index ketiga formula dikategorikan memiliki nilai Carr Index yang kurang baik karena nilai Carr Index yang sangat baik adalah antara $5-15 \%{ }^{(17)}$.

Tabel 2. Hasil uji sifat fisik tablet ekstrak buah mahkota dewa

\begin{tabular}{|c|c|c|c|}
\hline \multirow{2}{*}{$\begin{array}{c}\text { Sifat Fisik } \\
(X \pm S D)\end{array}$} & \multicolumn{3}{|c|}{ Formula } \\
\hline & T & II & III \\
\hline Diameter (mm) & $9,03 \pm 0,01$ & $9,02 \pm 0,01$ & $9,02 \pm 0,01$ \\
\hline $\mathrm{CV}(\%)$ & 0,11 & 0,11 & 0,11 \\
\hline Ketebalan (mm) & $3,18 \pm 0,28$ & $2,88 \pm 0,31$ & $3,00 \pm 0,24$ \\
\hline CV (\%) & 8,81 & 10,76 & 8,00 \\
\hline Keseragaman bobot $(\mathrm{g})$ & $200,9 \pm 4,39$ & $197,45 \pm 8,35$ & $200,5 \pm 1,87$ \\
\hline CV $(\%)$ & 2,19 & 4,23 & 0,93 \\
\hline Kekerasan (kg) & $6,90 \pm 0,52$ & $7,55 \pm 0,35$ & $8,33 \pm 0,21$ \\
\hline Waktu hancur (menit) & $7,38 \pm 0,21$ & $7,37 \pm 0,11$ & $8,49 \pm 0,08$ \\
\hline Kerapuhan (\%) & $0,15 \pm 0,04$ & $0,06 \pm 0,01$ & $0,13 \pm 0,03$ \\
\hline $\begin{array}{ll}\text { Keterangan : } & \\
\text { Formulasi I } & \text { : Suhu p } \\
\text { Formulasi II } & \text { : Suhu p } \\
\text { Formulasi III } & : \text { Suhu p }\end{array}$ & ingan ekstra & $\begin{array}{l}\partial^{\circ} \mathrm{C} \\
{ }^{\circ} \mathrm{C} \\
10^{\circ} \mathrm{C}\end{array}$ & \\
\hline
\end{tabular}


Hasil uji organoleptik secara keseluruhan tablet ekstrak buah mahkota dewa yang dihasilkan seragam yaitu berbentuk bulat, memiliki aroma yang khas, rasa pahit, dan berwarna cokelat muda. Dari hasil pada tabel ketiga formula tablet memiliki nilai CV untuk keseragaman diameter di bawah $5 \%$ sedangkan nilai CV untuk keseragaman ketebalan di atas $5 \%$ sehingga ketiga formula yang dihasilkan memiliki keseragaman ukuran yang kurang baik.

Hasil uji keseragaman bobot menunjukkan bahwa harga CV bahwa formula I dan III memenuhi persyaratan bobot tablet dan formula II telah memenuhi syarat keseragaman bobot karena memiliki harga CV $<6 \%$, dimana tablet dikatakan memiliki bobot yang seragam apabila nilai standar deviasi relatif atau coefficient of variation (CV) yang diperoleh $<6 \%{ }^{(18)}$.

Berdasarkan hasil uji kekerasan ketiga formula memiliki tingkat rata-rata kekerasan yang baik, denganperbedaan kekerasan tablet yang signifikan antara formula I, formula II dan formula III $(p<$ 0,05). Perbedaan ini menunjukkan adanya pengaruh suhu pengeringan spray dryer terhadap kekerasan tablet ekstrak buah mahkota dewa yang dihasilkan, yaitu semakin tinggi suhu pengeringan spray dryer semakin keras tablet yang dihasilkan. Hal ini dapat terjadi karena adanya perbedaan porositas, pada tablet formula III porositasnya lebih rendah dibandingkan dengan formula I dan formula II sehingga ikatan antar partikelnya menjadi lebih kuat dan kekerasannya menjadi lebih tinggi. Faktor lain yang mempengaruhi kekerasan tablet yaitu kecepatan mesin, kebersihan alat, perubahan distribusi ukuran partikel granulasi selama kompresi.

Tablet dikatakan baik jika memiliki kerapuhan kurang dari $1 \%{ }^{(18)}$. Berdasarkan hasil penelitian yang dapat dilihat pada grafik gambar 14 dan tabel VII, ketiga formula memiliki nilai kerapuhan yang baik karena memiliki kerapuhan kurang dari $1 \%$.

Hasil uji waktu hancur yang diperoleh menunjukkan bahwa antara waktu hancur formula I, II dan formula III berbeda secara signifikan yaitu formula I dan II lebih cepat hancur dibandingkan dengan formula III, sedangkan formula I dan II tidak memiliki waktu hancur yang berbeda secara signifikan ( $p$ $<0,05$ ). Adanya perbedaan waktu hancur disebabkan karena adanya peningkatan suhu pengeringan spray dyer yang menyebabkan pori-pori granul semakin mampat, porositasnya semakin kecil dan ikatan partikel penyusun tablet semakin kuat, tablet yang dihasilkan semakin keras sehingga waktu hancurnya semakin lama. Serbuk ekstrak buah mahkota dewa hasil spray dryer bersifat higroskopis yang mana akan menyerap lembab sehingga ikatan partikel pada tablet semakin kuat dan air sulit masuk ke dalam pori-pori tablet untuk menembus bahan penghancurnya yaitu primojel, oleh karena itu waktu hancurnya menjadi lama. Selain itu waktu hancur tablet dapat dipengaruhi oleh kekuatan pengempaan yang akan mempengaruhi kekerasan tablet yang dihasilkan dimana pada formula I memiliki kekerasan yang paling rendah dan formula III memiliki kekerasan paling tinggi. Semakin tinggi kekerasan tablet maka ikatan antar partikel penyusun tablet semakin kuat sehingga dapat menghambat laju penetrasi air ke dalam tablet dan menyebabkan waktu hancurnya semakin lama.

Pengujian aktivitas antioksidan dilakukan dengan pemeriksaan antiradikal bebas menggunakan radikal DPPH (2,2-Diphenyl-1-picrylhydrazyl), kemudian aktivitas antioksidan diukur berdasarkan kemampuan suatu senyawa atau sampel mengurangi intensitas warna larutan DPPH pada panjang gelombang $515 \mathrm{~nm}^{(19)}$. DPPH merupakan suatu molekul radikal bebas berwarna ungu yang dapat berubah menjadi senyawa stabil dengan warna kuning karena reaksinya dengan antioksidan, dimana antioksidan memberikan satu elektronnya pada DPPH sehingga terjadi peredaman radikal bebas. Pembanding yang digunakan pada uji aktivitas antioksidan ini adalah senyawa tokoferol. Tokoferol merupakan senyawa penyusun vitamin E yang mempunyai aktivitas antioksidan yang sangat tinggi, hanya dengan kadar yang sedikit sudah dapat meredam radikal bebas dan mudah didapatkan. Peredaman radikal bebas ditandai dengan menurunnya absorbansi DPPH serta berkurangnya intensitas warna ungu dari larutan DPPH setelah larutan tokoferol, ekstrak dan tablet dicampurkan dalam tabung reaksi. Uji aktivitas antioksidan DPPH berdasarkan reaksi penangkapan radikal DPPH oleh senyawa antioksidan melalui mekanisme donasi atom hidrogen sehingga akan dihasilkan DPPH$\mathrm{H}$ (bentuk non radikal) dan menyebabkan terjadinya penurunan intensitas warna ungu dari $\operatorname{DPPH}^{(20)}$. Parameter yang digunakan untuk mengintepretasikan hasil uji aktivitas antioksidan dengan adalah nilai persen persen aktivitas penghambatan radikal bebas, dimana semakin tinggi nilai yang didapat maka semakin tinggi aktivitas penghambatan radikal bebas yang terjadi.

Pada penelitian ini konsentrasi DPPH yang digunakan sebesar 25 ppm dengan panjang gelombang maksimum yang diperoleh $515,5 \mathrm{~nm}$ dan absorbansi 0,706 . Berikut ini tabel hasil absorbansi uji aktivitas antioksidan pada tokoferol, ekstrak buah mahkota dewa, dan tablet ekstrak buah mahkota dewa. 
Tabel 3. Hasil uji aktivitas antioksidan tablet ekstrak buah mahkota dewa

\begin{tabular}{|l|c|}
\hline \multicolumn{1}{|c|}{ Sampel } & $\begin{array}{c}\text { Aktivitas penghambatan } \\
\text { radikal bebas } \\
(\%) \pm \text { SD }\end{array}$ \\
\hline Tokoferol & $89,81 \pm 0,25$ \\
\hline $\begin{array}{l}\text { Ektrak buah mahkota } \\
\text { dewa }\end{array}$ & $87,35 \pm 0,22$ \\
\hline Tablet formula I & $6,80 \pm 2,85$ \\
\hline Tablet formula II & $3,68 \pm 0,73$ \\
\hline Tablet formula III & $1,84 \pm 0,87$ \\
\hline $\begin{array}{l}\text { Keterangan : kadar sampel yang digunakan } 25 \mu \mathrm{g} / \mathrm{ml}, \\
\text { pada sampel tablet dilakukan konversi sesuai bobot tablet }\end{array}$
\end{tabular}

Dari data yang tersaji di tabel 3 menunjukkan bahwa terjadi penurunan persen aktivitas penghambatan radikal bebas DPPH setelah ekstrak buah mahkota dewa diformulasi menjadi sediaan tablet sehingga dapat disimpulkan proses formulasi ekstrak buah mahkota dewa menjadi sediaan tablet mempengaruhi aktivitas antioksidan ekstrak buah mahkota dewa. Terdapat perbedaan signifikan antara persen aktivitas penghambatan radikal bebas DPPH formula I dan formula III sedangkan antara formula I dan II serta formula II dan III terdapat perbedaan namun tidak signifikan.

Dari hasil uji aktivitas antioksidan ini dapat disimpulkan bahwa adanya variasi suhu pengeringan spray dryer atau semakin tinggi suhu yang digunakan pada proses pengeringan ekstrak buah mahkota dewa semakin kecil aktivitas antioksidan tablet ekstrak buah mahkota dewa. Hal ini dimungkinkan karena senyawa yang memiliki aktivitas antioksidan yang terkandung di dalam ekstrak buah mahkota dewa yaitu flavonoid telah mengalami kerusakan karena adanya pemanasan pada saat proses pengeringan ekstrak buah mahkota dewa dengan menggunakan spray dryer. Flavonoid merupakan golongan senyawa fenol yang memiliki sistem aromatik terkonjugasi. Sistem aromatik terkonjugasi ini mudah rusak pada suhu tinggi. Selain itu,beberapa golongan flavonoid memiliki ikatan glikosida dengan molekul gula. Ikatan glikosida akan mudah rusak atau putus pada suhu tinggi. Faktor lain yang diduga berpengaruh adalah kondisi alat pengering ekstrak buah mahkota dewa yaitu spray dyer yang kurang optimal dan penambahan maltodekstrin dalam konsentrasi yang cukup besar sebelum ekstrak buah mahkota dewa cair dikeringkan menggunakan spray dryer sehingga mempengaruhi kandungan ekstrak pada serbuk yang dihasilkan yang kemudian berdampak pada penurunan aktivitas antioksidan secara signifikan setelah serbuk ekstrak diformulasi menjadi sediaan tablet.

\section{Kesimpulan}

Berdasarkan hasil penelitian, tablet dengan suhu pengeringan $70^{\circ} \mathrm{C}$ menghasilkan kekerasan 6,9 $\pm 0,52 \mathrm{~kg}$ dan waktu hancur $7,38 \pm 0,21$ menit, tablet dengan suhu pengeringan $90^{\circ} \mathrm{C}$ menghasilkan kekerasan $7,55 \pm 0,35 \mathrm{~kg}$ dan waktu hancur $7,37 \pm 0,11$ menit, tablet dengan suhu pengeringan $110^{\circ} \mathrm{C}$ menghasilkan kekerasan $8,33 \pm 0,21 \mathrm{~kg}$ dan waktu hancur 8,49 $\pm 0,08$ menit. Adanya variasi suhu pengeringan spray dryer pada suhu $70^{\circ} \mathrm{C}, 90^{\circ} \mathrm{C}$ dan $110^{\circ} \mathrm{C}$ dapat memberikan pengaruh terhadap sifat fisik tablet ekstrak buah mahkota dewa (Phaleria macrocarpa Boerl.) yaitu semakin tinggi suhu pengeringan spray dryer semakin tinggi kekerasan tablet yang dihasilkan sehingga berpengaruh pada waktu hancur tablet.

Berdasarkan hasil penelitian, tablet dengan suhu pengeringan $70^{\circ} \mathrm{C}, 80^{\circ} \mathrm{C}$, dan $90^{\circ} \mathrm{C}$ menghasilkan persen penghambatan radikal bebas DPPH berturut-turut adalah $6,80 \pm 2,85 \%, 3,68 \pm 0,73 \%$, dan 1,84 $\pm 0,87 \%$. Dari ketiga formula didapatkan bahwa adanya variasi suhu pengeringan spray dryer yaitu pada suhu $70^{\circ} \mathrm{C}, 90^{\circ} \mathrm{C}$ dan $110^{\circ} \mathrm{C}$ memberikan pengaruh terhadap aktivitas antioksidan tablet ekstrak buah mahkota dewa (Phaleria macrocarpa Boerl.), dimana semakin tinggi suhu pengeringan spray dryer maka semakin rendah aktifitas antioksidannya.

\section{Daftar Pustaka}

[1] Goeswin, A., Teknologi Bahan Alam, Penerbit ITB Bandung, 2007, hal. 1, 69.

[2] Wiryowidagdo, S, Kimia dan Farmakologi Bahan Alam Edisi 1, Penerbit Buku Kedokteran EGC, 2007, hal. 1-3.

[3] Burkill, I.H., A Dictionary of the Economic Products of the Malay Penninsula, Volume II, Ministry of Agriculture and Co-operatives, pp. 1732. 1966. 
[4] Oshimi, S., Zaima, K., Matsuno, Y., Hirasawa, Y., lizuka, T., Studiawan, H., Indrayanto, G., Zaini, N.C., and Morita, H., Studies on the constituents from the fruits of Phaleria macrocarpa, J. Nat. Med., 62: 207-210, November 2008.

[5] Harmanto, N., Mahkota Dewa Obat Pusaka Para Dewa, Penerbit Agromedia, Jakarta, 19. Hendra, R., Ahmad, S., Sukari, A., et al., 2011, Flavonoid Analyses and Antimicrobial Activity of Various Parts of Phaleria macrocarpa (Scheff.) Boerl Fruit, International Journal of Molecular Sciences, 12: 3422-3431. May 2011

[6] Soeksmanto, A., Hapasari, Y., dan Simanjuntak, P., Kandungan Antioksidan pada beberapa tanaman Mahkota Dewa, Biodiversitas, Vol. 8, No. 2: 92-95, April 2007.

[7] Syukri Y., Saepudin, Aktivitas Antikarsinogenesis Ekstrak Etanol Daging Buah Mahkota Dewa pada Mencit yang Diinduksi 7,12-Dimetilbenz(a)antrasena, Jurnal IImu Kefarmasian Indonesia, 6 (2): 63-67. Agustus 2008.

[8] Borris, R.P., G. Blasko, dan G.A. Cordell. 1988. Ethnopharmacologic and phytochemical studies of the Thymelaeaceae. J. Etnopharmacologiy, 24: 41, September 1988.

[9] Yuliani, S.H., Fudholi, A., dan Wahyuono, S., 2003, Optimasi Formula Tablet Kempa Langsung Perasan Bengle (Zingiber purpureum Roxb) Powder Tablet, Sains Kesehatan 16(1), Januari 2003.

[10] Soeksmanto, A., 2006, Effect of butanol extract of maturated mahkota dewa (Phaleria macrocarpa) fruit on kidney tissue of Mice, Biodeversitas, Vol. 7, No. 3: 278-281, Juli 2006.

[11] Leon L., Herbert A.L., Joseph L.K.,1989, Teori dan Praktek Farmasi Industri, Penerbit Universitas Indonesia, UI Press, hal. 3, 1989.

[12] Kurniawan, D.W., dan Sulaiman, T.N.S., 2009, Teknologi Sediaan Farmasi, Laboratorium Teknologi Farmasi, Graha Ilmu, hal. 80-81, 2009.

[13] Snyder, H.E., Spray Drying: Theory and Pharmaceutical Applications, Nektar Therapeutics, San Carlos, California, USA, pp. 227-247, 2008.

[14] Parry, J.S., and Dongreen, Perry's Chemical Engineers Handbook, McGraw-Hill Book Co., 1984.

[15] Kramer, J., Grady, L. T., Gajendran, J., Historical Development of Dissolution Testing, In Dressman, Jennifer, Pharmaceutical Dissolution Testing, Taylor \& Francis Group, LLC, United State of America, pp. 1-4, 2005

[16] Allen Jr., L. V., Luner, P. E., Magnesium Stearate, in Rowe, R. C., Sheskey, P. J., and Quinn, M. E., (Ed.). Handbook of Pharmaceutical Excipients, Sixth Edition, Pharmaceutical Press, pp. 404-406, 2009.

[17] Gordon, R.D., Roanoke, T.X., Fonner, D.E., Anderson, N.R. and Banker, G.S., 1990, Granulation Technology and Tablet Characterization, In Liberman H.A., Lachman, L., and Schwartz, J.B., (Eds.), Pharmaceutical Dosage Forms: Tablets, Second Edition, Vol 2, Marcel Dekker Icn,, pp. 317-320, 327, 338,339. 1990.

[18] Anonim, British Pharmacopeia, The Stationery Office on Behalf of The Medicines and Healthcare Product Regulatory Agency, 2007.

[19] Prior, R.L., Wu, X. dan Schaich, K. (2005). Standardized methods for the determination of antioxidant capacity and phenolics in foods and dietary supplements. Journal of Agriculture and Food Chemistry 55: 2698A-J

[20] Windono, T., dkk., 2004, Studi Hubungan Struktur-Aktivitas Kapasitas Peredaman Radikal Bebas Senyawa Flavonoid terhadap 1,1-Difenil-2-Pikrilhidrazil ( DPPH ), Artocarpus 4(1), 42-52. 